Sketsa Bisnis Volume (6) No (2) (2019) pp (125-136)

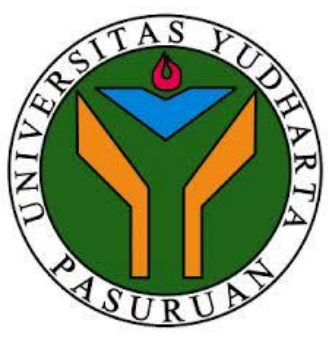
SKETSA BISNIS

Naskah Diterima : 20 Oktober 2019

Diterima Publikasi : 10 Desember 2019

Journal Homepage

https://jurnal.yudharta.ac.id/v2/index.php/SKETSABISNIS

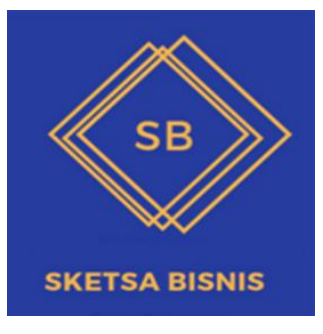

\title{
Pengaruh Pendidikan Kewirausahaan, Karakter Wirausaha Terhadap Intensi Berwirausaha Dengan Motivasi Usaha Sebagai Intervening
}

Phutry Lelliezza $^{1}$, Ali Musadeq ${ }^{2}$, Arik Prasetya ${ }^{3}$

Fakultas IImu Administrasi Universitas Brawijaya Malang

\begin{abstract}
This study aims to determine the effect of entrepreneurship education and entrepreneurial character on entrepreneurial intentions. In addition, it also aims to determine the role of business motivation as a mediator in this study. The population of this study is the Students of the Department of Business Administration, Faculty of Administrative Sciences, Brawijaya University, Malang, East Java, with a sample of 66 respondents. The sampling technique used was a proportional simple random technique. This study used a Path Analysis technique. The results showed that entrepreneurship education had a significant effect on entrepreneurial character and entrepreneurial intentions. Then entrepreneurship education also has direct and indirect effects through business motivation as an intervening variable.
\end{abstract}

Keywords: Entrepreneurship, Entrepreneurship Education, Character of Entrepreneurship, Business Motivation, and Entrepreneurial Intentions

\begin{abstract}
Abstrak
Penelitian ini bertujuan untuk mengetahui pengaruh pendidikan kewirausahaan dan karakter wirausaha terhadap intensi berwirausaha, Selain itu, juga bertujuan untuk mengetahui peran motivasi usaha sebagai mediator dalam penelitian ini. Populasi penelitian ini yaitu Mahasiswa Jurusan Administrasi Bisnis, Fakultas Ilmu Administrasi, Universitas Brawijaya, Malang, Jawa Timur, dengan sampel berjumlah 66 responden. Teknik Pengambilan sampel dengan teknik random sederhana yang proporsional.Penelitian ini menggunakan teknik Analisis Path.Hasil penelitian menunjukkan bahwa pendidikan kewirausahaan berpengaruh signifikan terhadap karakter wirausaha dan intensi berwirausaha. Kemudian pendidikan kewirausahaan juga berpengaruh langsung dan tidak langsung melalui motivasi usaha sebagai variabel intervening.
\end{abstract}

Keywords: Kewirausahaan, Pendidikan Kewirausahaan, Karakter Wirausaha, Motivasi Usaha, dan Intensi Berwirausaha.

*) Penulis Korespondensi: Phutrylelliezza@gmail,com 


\section{Pendahuluan}

Persoalan ekonomi dapat diberikan solusi salah satunya melalui pengembangan kewirausahaan, khususnya untuk mendorong pertumbuhan ekonomi dan perkembangan teknologi (Sumarsono, 2010). Salah satu indikator dari kemajuan aktifitas kewirausahaan dapat dilihat dari persentase penduduk yang memilih berkarir sebagai wirausaha. (Saiman, 2009) menyatakan bahwa agar suatu negara bisa menjadi makmur dibutuhkan minimum $2 \%$, hal ini sebagai indikasi bahwa sebagai negara yang berkembang Indonesia masih harus meningkatkan jumlah penduduk sebagai wirausahawan yang memiliki berbagai keunggulan untuk membantu meningkatkan ekonomi bangsa.

Indonesia hanya mampu memiliki penduduk sebagai wirausaha $1.73 \%$ dari total penduduk sebesar kurang lebih 260 Juta penduduk (BPS, 2017). Dengan tingginya jumlah penduduk Indonesia namun jumlah pengusaha yang masih sedikit menjadi sebuah masalah baru yang muncul yaitu pengangguran. Terlebih lagi pengangguran banyak terjadi pada usia kerja dan merupakan lulusan pendidikan tinggi. Berikut ini merupakan data pengangguran terbuka Indonesia terbaru yaitu :

Tabel 1.1 Pengangguran terbuka Indonesia Tahun 2016-2018

\begin{tabular}{|l|r|r|r|}
\hline \multirow{2}{*}{ Pendidikan } & \multicolumn{3}{|c|}{ Tahun } \\
\cline { 2 - 4 } & 2016 & 2017 & 2018 \\
\hline $\begin{array}{l}\text { Diploma } \\
\text { I.II.III/akademi }\end{array}$ & $4 \%$ & $3 \%$ & $4 \%$ \\
\hline Universitas & $7 \%$ & $8 \%$ & $8 \%$ \\
\hline
\end{tabular}

Sumber : BPS 2018 (data diolah)

Berdasarkan Tabel 1.1 ternyata terdapat hal menarik yang diketahui bahwa kontribusi lulusan pendidikan tinggi di Indonesia terhadap pengangguran juga besar dan cenderung meningkat dari tahun ke tahun. Pada tahun 2016 lulusan universitas memiliki jumlah kontribusi $7 \%$ dari pengangguran terbuka Indonesia, kemudian naik menjadi $8 \%$ pada tahun 2017. Hal yang sama terjadi pada lulusan diploma yang seharusnya bisa menyerap tenaga kerja lebih banyak tetapi pengangguran justru naik dari tahun 2017 ke tahun 2018 sebanyak 1\%. Hal ini menunjukkan bahwa lulusan pendidikan tinggi belum menjadi jaminan akan berkontribusi pada pengurangan jumlah pengangguran terbuka di Indonesia. Hal tersebut masih menjadi sebuah permasalahan yang harus mampu diselesaikan oleh berbagai pihak, khususnya pihak pendidikan tinggi sendiri sebagai penyelenggara pendidikan untuk mengurangi jumlah pengangguran dari penduduk yang lulus perguruan tinggi.

(Darpujianto, 2014) menyatakan bahwa sampai sebanyak $82.2 \%$ lulusan perguruan tinggi bekerja sebagai pegawai.Lulusan perguruan tinggi cenderung menjadi pencari kerja dan sedikit yang menjadi pengusaha.Masa tunggu lulusan perguruan tinggi yang mencapai 6 bulan hingga 3 tahun menjadi masalah besar yang secara otomatis meningkatkan jumlah pengangguran terdidik di Indonesia. Salah satu solusi yang baik peranan wirausahawan bagi suatu negara dapat menciptakan lapangan pekerjaan yang baru dan lebih besar menyerap tenaga kerja.Berkaitan dengan kewirausahaan yang menjadi perhatian banyak pihak, terdapat teori yang mendukung keberadaan kewirausahaan di suatu negara. Teori "Penta Helix" yang menekankan bahwa sinergi antara Civil Society, Goverment,Entrepreneur, Media dan juga Universtiy dalam hal ini yaitu universitas yang didalamnya terdapat para akademisi dengan berbagai latar belakang keilmuan.

Dari kelima pihak yang dijelaskan pada teori pentahelix tersebut, perhatian tertuju pada peran pihak lembaga pendidikan tinggi atau universitas untuk membentuk para wirausahawan yang memiliki kemampuan dengan bekal sebagai lulusan 
pendidikan tinggi.Peran universitas dapat dimaksimalkan dengan pembentukan kurikulum yang didalamnya terdapat peningkatan kesadaran dan keahlian dalam berwirausaha dalam bentuk pendidikan kewirausahaan. (Souitaris et al., 2007) menyatakan bahwa pendidikan kewirausahaan merupakan tahapan yang dilalui seseorang dimulai dari informasi mengenai dunia kewirausahaan, memberikan bekal potensi dan keahlian kewirausahaan serta yang terakhir tentu memberikan rangsangan bagi wirausaha untuk memulai bisnis.

Rangsangan bagi wirausaha tentu bertujuan untuk menumbuhkan motivasi yang lebih tinggi, berawal dari tujuan seseorang saat masuk perguruan tinggi untuk mendapat pekerjaan lebih baik di masa depan dan pada proses pendidikan didalamnya ternyata merubah pemikiran yang selama ini mencari kerja dan berubah menjadi wirausaha yang ingin menciptakan pekerjaan. Hal tersebut merupakan bentuk pendidikan kewirausahaan yang menciptakan motivasi bagi seseorang agar memilih kewirausahaan sebagai tujuan yang ingin dicapai. (Hytti et al., 2010) menyatakan bahwa motivasi menjadi wirausaha bisa dibentuk dengan pola pendidikan kewirausahaan yang tersistematis dan terukur dalam prosesnya.

Berkaitan dengan motivasi, setiap orang tentu memiliki respon berbeda-beda terhadap stimulus yang akan mempengaruhi motivasi. Salah satunya adalah perbedaan karakter wirausaha seseorang. (Hussain et al., 2008) menyatakan bahwa karakter wirausaha merupakan identitas yang melekat pada diri seseorang berdasarkan kondisi lingkungan sosial, keluarga, budaya, dan pendidikan yang diperoleh. Selain itu, Karakter wirausaha menurut (Robert et al .2007) merupakan suatu proses psikologi yang mempengaruhi wirausaha dalam memperoleh, menerima barang dan jasa serta pengalaman.

Berdasarkan pemaparan teori-teori tersebut dapat diketahui bahwa karakter wirausaha merupakan sikap yang melekat pada wirausaha dengan keanekaragaman yang dimiliki dan menjadi identitas seseorang dalam kehidupan sosialnya. Peran pendidikan dan karakter yang dikembangkan untuk meningkatkan motivasi akan bermuara pada intensi berwirausaha dalam membuat keputusan untuk menjadi entrepreneur.

Tingkat intensi berwirausaha merupakan sikap akhir yang menjadi tujuan bagi lembaga pendidikan misalnya, untuk mendorong seseorang sebagai lulusan pendidikan tinggi menjadi pengusaha.(Ali, 2013) menyatakan bahwa intensi terhadap kesadaran berwirausaha merupakan bentuk dari kesadaran seseorang untuk berwirausaha dengan lebih fokus. Penelitian ini juga dikembangkan dari beberapa perbedaan hasil penelitian terdahulu yaitu (Farhangmehr et al., 2016) yang menyatakan hasil penelitian berkaitan pendidikan kewirausahaan dan motivasi yang memiliki hasil tidak signifikan, sedangkan pada peneliti lain (Husaen et al., 2017) ternyata memiliki hasil yang berpengaruh positif atau signifikan. Oleh karena perbedaan tersebut penelitian ini menjadikan celah atau gap penelitian yang masih terjadi pertentangan (conclusive) untuk di teliti dan di analisis lebih lanjut.

Proses pendidikan kewirausahaan dalam berbagai perguruan tinggi sudah banyak dikembangkan untuk menunjang daya saing lulusan perguruan tinggi. Salah satu lembaga yang sudah melaksanakannya yaitu Fakultas IImu Administrasi Universitas Brawijaya (FIA UB), Malang.Lembaga yang berdiri sejak tahun 1963 ini memiliki berbagai program studi yang salah satunya adalah IImu Administrasi Bisnis.Berbagai lembaga pendidikan tinggi yang menggunakan Tagline utama Bisnis yang lebih fokus 
terhadap kurikulum pendidikan kewirausahaan menjadikan tema bisnis ternyata lebih menarik untuk dikembangkan. Berkaitan dengan hal tersebut FIA UB lebih mampu bersaing dengan berbagai lembaga lain untuk menjadikan pendidikan kewirausahaan sebagai salah satu perhatian penting. Akan tetapi yang terjadi selama ini mahasiswa FIA UB memiliki berbagai masalah dalam hal menentukan masa depannya. Perbedaan karakter mahasiswa yang beragam menjadikan proses mengarahkan pendidikan bagi mahasiswa menjadi sulit untuk lebih fokus.

Mengangkat tema salah satu jurusannya yaitu administrasi bisnis seharusnya menjadi tantangan bagi FIA UB untuk lebih mampu mempertajam kualitas pendidikan berkaitan dengan bisnis atau membentuk jiwa-jiwa entrepreneur baru yang dihasilkan oleh lulusan FIA UB. Berdasarkan analisis peneliti bahwa problema pilihan karir menjadi sesuatu yang sulit dihadapi para mahasiswa FIA UB, disatu sisi mahasiswa ingin menjadi seorang pegawai dalam perusahaan karena ilmu pengetahuan tentang tata kelola perusahaan yang diberikan pada fakultas, namun di sisi lain pilihan karir sebagai pelaku bisnis ketika mempercayakan keputusan untuk menempuh pendididkan tinggi di FIA UB.

Selanjutnya rumusan masalah dalam penelitian ini yaitu,

1. Apakah pendidikan kewirausahaan berpengaruh secara signifikan terhadap motivasi usaha?

2. Apakah karakter wirausaha berpengaruh secara signifikan terhadap motivasi usaha?

3. Apakah pendidikan kewirausahaan berpengaruh secara signifikan terhadap intensi berwirausaha?

4. Apakah karakter wirausaha berpengaruh secara signifikan terhadap intensi berwirausaha?

5. Apakah motivasi usaha berpengaruh secara signifikan terhadap intensi berwirausaha?
6. Apakah Pendidikan Kewirausahaan berpengaruh tidak langsung terhadap Intensi berwirausaha?

7. Apakah Karakter Wirausaha berpengaruh tidak langsung terhadap Intensi berwirausaha?

\section{Kerangka Teori}

Penelitian ini mengembangkan teori tentang pendidikan kewirausahaan (Bygrave, 1998) dari tiga faktor yaitu:

1. Aspek kognitif yaitu aspek wawasan dan pengetahuan yang menjadi sebuah skill ketika dipelajari oleh wirausaha.

2. Aspek afektif yaitu aspek perasaan atau stimulus wirausaha sehingga memunculkan rasa tertarik pada bidang atau ilmu tertentu

3. Aspek psikomotor yaitu kemampuan wirausaha yang mengembangkan kognitif dan afektif menjadi sebuah praktek atau penerapan dilapangan.

Pendidikan bisnis di perguruan tinggi meliputi pendidikan pekerja, distribusi dan pemasaran dan pemahaman konsep ilmu ekonomi, dan dipraktekkan dalam suatu usaha bisnis nyata.Pendidikan bisnis sebenarnya dapat dilakukan pada setiap level pendidikan, mulai dari pendidikan dasar hingga di perguruan tinggi. Di dalam perguruan tinggi bidang kejuruan, pendidikan bisnis akan sangat berkontribusi mempersiapkan lulusan mahasiswanya menjadi pekerja bisnis yang mahir dan mampu memimpin suatu usaha bisnis.

Menurut (Ali, 2013) menyatakan bahwa pendidikan kewirausahaan merupakan upaya menginternalisasikan jiwa dan mental kewirausahaan baik melalui institusi pendidikan maupun institusi lain seperti lembaga pelatihan, training dan sebagainya. Selanjutnya, menurut Farhangmehr et al., (2016) menyatakan bahwa "the process of transmitting entrepreneurial knowledge and skills to students to help them exploit a 
business opportunity" (proses transmisi pengetahuan dan keterampilan kewirausahaan kepada siswa untuk membantu mereka dalam memanfaatkan peluang bisnis). Berdasarkan penjelasan para ahli dapat disimpulkan bahwa pendidikan kewirausahaan merupakan upaya yang sistematis dalam rencana membantu memberi pengetahuan berkaitan dengan peluang bisnis yang masih terbuka lebar dan semakin berkembang untuk saat ini.

Berbagai sumber yang didapatkan oleh wirausaha berkaitan dengan pendidikan kewirausahaan salah satunya adalah melalui Universitas yang telah memasukkan mata kuliah kewirausahaan pada proses pembelajarannya. Hal tersebut sesuai dengan visi misi pemerintah saat ini yang lebih mengembangkan dunia wirausaha bagi para penerus bangsa melalui proses pendidikan kewirausahaan yang lebih banyak di semua lembaga pendidikan tinggi. Walaupun pada akhirnya lulusan perguruan tinggi memiliki berbagai variasi latar belakang lulusan dengan profesi yang berbeda tetapi pembelajaran kewirausahaan telah diterapkan pada berbagai bidang keilmuan atau jurusan (Susilaningsih, 2015).

Peran pemerintah melalui peraturan yang berfokus pada pengembangan dunia wirausaha pada lembaga pendidikan tinggi bukan berarti harus mengubah seluruh visi misi dan karakter sebuah lembaga menjadi sekolah atau universitas bisnis.

Karakter wirausaha menurut (Husain et al., 2008) merupakan ciri khas dari wirausaha yang melekat dan menjadi identitas setiap pribadi. Menurut penelitian (Husain et al., 2008) Karakter wirausaha berkaitan dengan sikap kewirausahaannya dapat dilihat melalui beberapa variabel demografi seperti jenis kelamin, usia, latar belakang sosial, dan latar belakang suku atau etnis yang dimiliki. Teori karakter wirausaha menurut (Bygrave, 1998) menyatakan bahwa seorang wirausaha harus memiliki karakter sebagai wirausaha yang dikenal dengan sebutan $10 \mathrm{D}$, yaitu : Dream, Dicisiveness, Doers, Determination, Dedication, Devotion, Details, Destiny, Dollars, dan Distribute. Karakter atau ciri-ciri yang dimiliki wirausaha dapat menjadi watak yang melekat kuat sebagai ciri khas yang menjadi pembeda dari orang lain. Watak tersebut dapat dibentuk melalui berbagai stimulus dan menjadikan keluaran atau hasil yang dapat berguna bagi proses pemilihan karir seseorang. (Robert et al., 2007) juga menyatakan bahwa karakter wirausaha dapat dimiliki seseorang karena berbagai faktor seperti faktor latar belakang keluarga, latar belakang sosial, lingkungan dan banyak lainnya.

Faktor-faktor tersebut membentuk karakter yang kuat kepada wirausaha dan menjadi ciri khas yang selama ini melekat pada diri seseorang. Berdasarkan pemaparan tentang karakter wirausaha yang dijelaskan, penelitian ini menggunakan teori karakter wirausaha yang dikembangkan ByGrave yaitu $10 \mathrm{D}$ mengenai karakter wirausaha yang harus dimiliki.

Penelitian ini juga mengembangkan motivasi usaha sebagai kajian teori.Motivasi didefinisikan oleh (Hytti et al., 2010) yaitu pengaruh dari internal dan eksternal untuk mempengaruhi perilaku wirausaha dalam kehidupan yang dijalani. Hal tersebut berarti faktor internal dan eksternal merupakan faktor yang dapat mendorong namun juga faktor penarik untuk seseorang dalam hal ini yaitu menumbuhkan motivasi berwirausaha. Menurut (Farhangmehr et al., 2016) motivasi adalah sebagai kondisi internal yang membangkitkan kita untuk bertindak, mendorong kita mencapai tujuan tertentu, dan membuat kita tetap tertarik dalam kegiatan tertentu.

Kemudian menurut (Souitaris et al., 2007) motivasi dapat diartikan sebagai 
dorongan internal dan eksternal dalam diri seseorang yang diindikasikan dengan adanya; hasrat dan minat; dorongan dan kebutuhan; harapan dan cita-cita; penghargaan dan penghormatan. Berdasarkan penjelasan para ahli dapat disimpulkan bahwa motivasi merupakan faktor pendorong dan penarik yang mempengaruhi seseorang untuk melakukan sesuatu dengan tujuan yang sudah ditetapkan.Motivasi Usaha dalam penelitian ini dikembangkan dari teori (Linan et al., 2011) yaitu Personal attitude, Perceived Social Norm, dan Self-Efficacy.

Penelitian ini juga membahas intensi berwirausaha Intensi atau niat untuk berwirausaha dapat didefinisikan sebagai kemampuan untuk mengubah pola pikiran, perilaku dan menunjukkan melalui minat yang diperoleh dari banyak faktor pendorong untuk melakukannya (Robert et al., 2007). Kecenderungan seseorang untuk melakukan atau tidak melakukan sesuatu, seperti memilih kewirausahaan sebagai pilihan karir, dapat diprediksi oleh Teori Perilaku Terencana (Theory of Planned Behavior-TPB).Menurut (Ali, 2013) menyatakan bahwa TPB sangat sesuai digunakan untuk menjelaskan berbagai perilaku di dalam kewirausahaan. Sebagaimana dikatakan oleh (Souitaris et al., 2008) bahwa TPB is suitable to explain any behavior which requires planning, such as entrepreneurship (TPB cocok untuk menjelaskan perilaku apa pun yang memerlukan perencanaan, seperti kewirausahaan).

\subsection{Hubungan Antar Variabel dan Hipotesis \\ (Souitaris et al., 2007) menyatakan} bahwa pendidikan kewirausahaan merupakan proses pelatihan dan mengarahkan seseorang untuk lebih mengenal kewirausahaan. Pendidikan kewirausahaan yang tersusun secara tepat mampu merangsang seseorang yang sebelumnya belum mengenal dunia kewirausahaan menjadi lebih tertarik atau termotivasi untuk memulai berwirausaha. (Farhangmehr et al., 2016) juga menyatakan bahwa pendidikan kewirausahaan menekankan pada peningkatan skill dan juga pengetahuan mengenai kewirausahaan, namun yang lebih penting adalah menumbuhkan motivasi untuk berwirausaha dan memulai sebuah bisnis. Berdasarkan hubungan yang dikembangkan maka hipotesis penelitian yaitu,

H.1 Pendidikan kewirausahaan berpengaruh signifikan terhadap motivasi usaha.

Karakter wirausaha menurut (Hytti et al., 2010) adalah minat, sikap, dan kebutuhan yang ingin dicapai dalam tujuan yang sudah seseorang rencanakan. Karakter wirausaha dalam penelitian ini menekankan pada pembelajaran yang selama ini didapatkan dari pendidikan formal ataupun dari pengalaman seseorang secara langsung. Menurut (Littunen, 2000) karakter wirausaha dapat diukur dengan proses belajar tentang wirausaha yang dapat meningkatkan motivasi seseorang dalam menjalankan bisnis. Karakter yang melekat dapat juga dilihat melalui faktor sosial seseorang misalnya latar belakang keluarga, gender, usia, pengalaman bisnis, atau tingkat pendidikan. Hal tersebut merupakan berbagai faktor yang mampu berpengaruh terhadap motivasi seseorang untuk memulai berwirausaha. Berdasarkan hubungan yang dikembangkan maka hipotesis penelitian yaitu.

H.2 Karakter wirausaha berpengaruh signifikan terhadap motivasi usaha

(Ali, 2013) menyatakan bahwa pendidikan dan pelatihan kewirausahaan berperan besar untuk menumbuhkan sikap dan intensi (niat) untuk berwirausaha. Proses pendidikan bertujuan untuk mengarahkan seseorang berdasarkan tujuan yang ingin dicapai, untuk mencapai tujuan tersebut disusun sistem pembelajaran yang mendukung agar 
seseorang memiliki intensi pada bidang kewirausahaan. (Linan et al., 2011) menyatakan bahwa proses pendidikan terdiri dari 3 proses, yaitu belajar, berlatih, dan berhasil.

Untuk mencapai keberhasilan seseorang harus melalui proses belajar berkaitan dengan wawasan ilmu kewirausahaan, kemudian proses berlatih hanya dapat dilakukan secara langsung (praktek) agar seseorang merasakan langsung proses berwirausaha. Pada proses berlatih tersebut intensi untuk berwirausaha semakin tinggi karena tujuan untuk berhasil semakin jelas dan membuat seseorang lebih tertarik akan dunia kewirausahaan. Berdasarkan hubungan yang ada maka hipotesis dalam penelitian ini, yaitu:

H.3 Pendidikan kewirausahaan berpengaruh signifikan terhadap intensi berwirausaha.

Intensi berwirausaha dapat dipengaruhi berbagai faktor dalam diri seseorang. Littunen (2010) menyatakan bahwa karakter latar belakang sosial dapat menjadi dasar seseorang untuk masuk dalam dunia kewirausahaan. Faktor tersebut misalnya latar belakang keluarga yang selama ini sudah menjalankan bisnis, atau faktor latar belakang pendidikan yang fokus pada ilmu kewirausahaan.

Karakter tersebut akan mampu membawa seseorang untuk lebih tertarik dalam bidang kewirausahaan. (Linan et al., 2011) juga menyatakan bahwa intensi berwirausaha dapat dikembangkan dari perilaku atau perceived feasibility, perilaku kewirausahaan dapat diperoleh dari stimulus yang berasal dari wawasan wirausaha terkait ilmu pengetahuan dunia wirausaha. Berdasarkan hubungan yang ada maka hipotesis dalam penelitian, yaitu: H.4 Karakter wirausaha berpengaruh signifikan terhadap intensi

berwirausaha

Hytti et al., (2010) menyatakan bahwa motivasi seseorang untuk memulai sebuah usaha dapat dipengaruhi oleh faktor intrinsic (internal) dan extrinsic (eksternal). Faktor internal dapat dimiliki seseorang berdasarkan rasa ingin tahu tentang dunia bisnis dan juga optimism yang besar dalam dirinya untuk menjalani sebuah bisnis. Faktor eksternal diperoleh melalui kondisi lingkungan misalnya melihat keberhasilan bisnis orang lain dalam lingkungan sekitar dapat meningkatkan rasa ketertarikan untuk memiliki intensi berwirausaha (Robert et al., 2007). Selain itu, (Linan et al., 2011) juga menyatakan bahwa motivasi usaha dapat meningkatkan intensi berwirausaha melalui tiga faktor yaitu personal attitude, perceived social norm, dan self-efficacy. Berdasarkan hubungan yang ada maka hipotesis dalam penelitian ini, yaitu:

H.5 Motivasi usaha berpengaruh signifikan terhadap intensi berwirausaha

Penelitian ini menggunakan model yang disusun dan dikembangkan dari beberapa kajian empiris terdahulu model pertama Gambaran model penelitian ini sebagai berikut, yaitu :

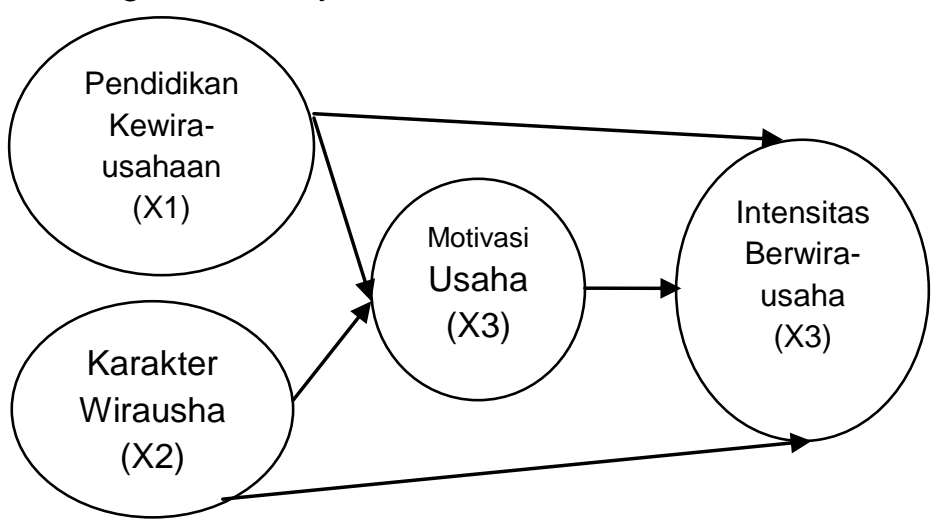

Sumber: Diolah Peneliti, 2019

Gambar 1. Gambaran Model Penelitian

\section{Metode}

Metode penelitian dengan explanatory research. Sampel yang digunakan adalah 66 responden mahasiswa FIA UB di Kota Malang, Jawa Timur. Instrumen kuesioner yang merupakan serangkaian pertanyaan sistematis digunakan dalam penelitian ini bertujuan untuk mengumpulkan data dari responden (Rakhmawati, Rahardjo \& 
Andriani, 2019) disebarkan dengan skala pengukuran likert .Pendidikan Kewirausahaan di ukur dengan indikator yaitu kognitif, afektif, dan psikomotor melalui tujuh item yang mengadopsi penelitian dari (Bygrave, 1998) tentang teori $10 \mathrm{D}$, dan juga (Souitaris et al., 2007) serta (Ali, 2013). Karakter wirausaha diukur dengan penelitian (Bygrave, 1998) melalui teori 10 D, dan (Patan et al., 2015), (Darpujianto, 2014). Motivasi usaha dikembangkan dari temuan penelitian (Hyyti et al., 2010), (Robert et al., 2007) dan (Hussain et al., 2008) dengan indikator Personal Attitude, Perceived Social Norm, dan Self-Efficacy. Intensi berwirausaha mengadopsi penelitian dari (Krueger, 2014) dan (Linan et al., 2011).

\section{Hasil Penelitian dan Pembahasan}

4.1 Hasil Uji Hipotesis

H.1 Hasil penelitian menunjukkan pendidikan kewirausahaan berpengaruh signifikan terhadap motivasi usaha dengan nilai koefisien $0,318 \mathrm{P} \leq 0.005$, diterima. Hasil penelitian ini menyatakan bahwa pendidikan kewirausahaan yang dilakukan pada mahasiswa sebagai responden terbukti berpengaruh signifikan terhadap motivasi usaha. Hal tersebut sesuai dengan beberapa peneliti terdahulu yaitu (Souitaris et al., 2007) menyatakan bahwa pendidikan kewirausahaan merupakan proses pelatihan dan mengarahkan seseorang untuk lebih mengenal kewirausahaan. Pendidikan kewirausahaan yang tersusun secara tepat mampu merangsang seseorang yang sebelumnya belum mengenal dunia kewirausahaan menjadi lebih tertarik atau termotivasi untuk memulai berwirausaha.Selain itu, teori dasar pendidikan kewirausahaan yang dinyatakan oleh (Bygrave, 1990) menyatakan bahwa pendidikan untuk menciptakan para pebisnis adalah metode yang tepat baik melalui formal maupun informal dengan pengalaman langsung.

H.2 Hasil penelitian menunjukkan karakter wirausaha berpengaruh signifikan terhadap motivasi usaha dengan nilai $0,599 \mathrm{P} \leq 0.05$, diterima. Hasil penelitian ini menyatakan bahwa karakter wirausaha ternyata berpengaruh signifikan terhadap motivasi. Hal tersebut sesuai dengan beberapa penelitian terdahulu yaitu menurut (Hytti et al., 2010) menyatakan minat, sikap, dan kebutuhan yang ingin dicapai dalam tujuan yang sudah seseorang rencanakan. Karakter wirausaha dalam penelitian ini menekankan pada pembelajaran yang selama ini didapatkan dari pendidikan formal ataupun dari pengalaman seseorang secara langsung. Menurut (Littunen, 2000) karakter wirausaha dapat diukur dengan proses belajar tentang wirausaha yang dapat meningkatkan motivasi seseorang dalam menjalankan bisnis. Karakter yang melekat dapat juga dilihat melalui faktor sosial seseorang misalnya latar belakang keluarga, gender, usia, pengalaman bisnis, atau tingkat pendidikan.

H.3 pendidikan kewirausahaan pada penelitian juga memiliki pengaruh signifikan terhadap intensi berwirausaha dengan nilai koefisien $0,226 \mathrm{P} \leq 0.05$, diterima. Hasil penelitian ini sesuai dengan penelitian (Ali, 2013) yang menyatakan bahwa pendidikan dan pelatihan kewirausahaan berperan besar untuk menumbuhkan sikap dan intensi (niat) untuk berwirausaha. Intensi merupakan kumpulan rangsangan yang bermuara menjadi minat atau tujuan, jika rangsangan tersebut dilakukan secara sistematis dan terus-menerus. Proses pendidikan bertujuan untuk mengarahkan 
seseorang berdasarkan tujuan yang ingin dicapai, untuk mencapai tujuan tersebut disusun sistem pembelajaran yang mendukung agar seseorang memiliki intensi pada bidang kewirausahaan. (Linan et al., 2011) menyatakan bahwa proses pendidikan terdiri dari 3 proses, yaitu belajar, berlatih, dan berhasil

$\mathrm{H} .4$ hasil penelitian ini menunjukkan karakter wirausaha berpengaruh signifikan terhadap intensi berwirausaha dengan nilai koefisien $0,322 \quad P<0.05$, diterima. Hasil penelitian ini menyatakan bahwa karakter wirausaha dapat berpengaruh signifikan terhadap niat berwirausaha, menurut beberapa peneliti terdahulu Intensi berwirausaha dapat dipengaruhi berbagai faktor dalam diri seseorang. Penelitian ini mendukung hasil dari (Littunen, 2010) menyatakan bahwa karakter latar belakang sosial dapat menjadi dasar seseorang untuk masuk dalam dunia kewirausahaan. Faktor tersebut misalnya latar belakang keluarga yang selama ini sudah menjalankan bisnis, atau faktor latar belakang pendidikan yang fokus pada ilmu kewirausahaan. Karakter tersebut akan mampu membawa seseorang untuk lebih tertarik dalam bidang kewirausahaan. (Linan et al., 2011) juga menyatakan bahwa intensi berwirausaha dapat dikembangkan dari perilaku atau perceived feasibility, perilaku kewirausahaan dapat diperoleh dari stimulus yang berasal dari wawasan wirausaha terkait ilmu pengetahuan dunia wirausaha.

H.5 Hasil penelitian menunjukkan bahwa motivasi usaha berpengaruh signifikan terhadap intensi berwirausaha dengan nilai koefisien $0,445 \mathrm{P} \leq 0.05$, diterima. Hasil penelitian ini mendukung penelitian Hytti et al., (2010) menyatakan bahwa motivasi seseorang untuk memulai sebuah usaha dapat dipengaruhi oleh faktor intrinsic (internal) dan extrinsic (eksternal). Faktor internal dapat dimiliki seseorang berdasarkan rasa ingin tahu tentang dunia bisnis dan juga optimism yang besar dalam dirinya untuk menjalani sebuah bisnis. Faktor eksternal diperoleh melalui kondisi lingkungan misalnya melihat keberhasilan bisnis orang lain dalam lingkungan sekitar dapat meningkatkan rasa ketertarikan untuk memiliki intensi berwirausaha (Robert et al., 2007). Selain itu, (Linan et al., 2011) juga menyatakan bahwa motivasi usaha dapat meningkatkan intensi berwirausaha melalui tiga faktor yaitu personal attitude, perceived social norm, dan self-efficacy. Berdasarkan teori kebutuhan Maslow menyatakan bahwa salah satu bagian puncak ketika seseorang sudah memenuhi kebutuhan dasarnya, selanjutnya adalah akan fokus pada kebutuhan aktualisasi diri melalui kebutuhan prestasi, pengakuan, barang mewah, ataupun kebebasan dalam manajemen waktu sehingga hal tersebut menjadi faktor intensi berwirausaha menjadi semakin tinggi.

Selain itu, pengaruh langsung dan tidak langsung dalam penelitian ini disajika dalam berikut yaitu;

Tabel 1.2 Hasil Pengujian Langsung dan Tidak Langsung

\begin{tabular}{|c|c|c|c|}
\hline Hub. Var. & $\begin{array}{c}\text { Pengaruh } \\
\text { Langsung }\end{array}$ & $\begin{array}{c}\text { Pengaruh } \\
\text { Tidak } \\
\text { Langsung } \\
\text { Melalui } \\
\text { Y1 }\end{array}$ & $\begin{array}{c}\text { Pengaruh } \\
\text { Total }\end{array}$ \\
\hline $\mathrm{X} 1 \rightarrow$ Y1 & 0,318 & - & 0,223 \\
\hline $\mathrm{X} 2 \rightarrow \mathrm{Y} 1$ & 0,599 & - & 0,259 \\
\hline $\mathrm{X} 1 \rightarrow \mathrm{Y} 2$ & 0,226 & - & 0,377 \\
\hline $\mathrm{X} 2 \rightarrow \mathrm{Y} 2$ & 0,322 & - & 0,383 \\
\hline $\mathrm{Y} 1 \rightarrow \mathrm{Y} 2$ & 0,445 & - & 0,234 \\
\hline $\begin{array}{c}\mathrm{X} 1 \rightarrow \mathrm{Y} 1 \\
\rightarrow \mathrm{Y} 2\end{array}$ & $0,141+(0,318 \mathrm{x}$ & 0,282 \\
\hline $\mathrm{X} 2$ & $0,445)$ & 0,532 \\
$\rightarrow$ Y1 $\rightarrow$ & $0,266+(0,599 \mathrm{x}$ & \\
Y2 & \multicolumn{2}{|c|}{$0,445)$} & \\
\hline
\end{tabular}

Sumber: Data Diolah Peneliti, 2019 


\section{Kesimpulan dan Saran}

\subsection{Kesimpulan}

Berdasarkan permasalahan yang telah dirumuskan, hasil analisis dan pengujian hipotesis yang telah dilakukan pada bab sebelumnya, maka dari penelitian yang dilakukan dapat diambil kesimpulan. Hasil penelitian menunjukan bahwa variabel pendidikan kewirausahaan berpengaruh positif dan signifikan terhadap motivasi usaha hasil tersebut sebagai pedoman bahwa pendidikan kewirausahaan dibutuhkan oleh mahasiswa sebagai wadah pengembangan kualitas soft skill kewirausahaan yang berdaya saing.

Hasil penelitian menunjukan bahwa variabel karakter wirausaha berpengaruh positif dan signifikan terhadap motivasi usaha, yang berarti bahwa salah satu cara untuk meningkatkan motivasi usaha mahasiswa adalah dengan metode pelatihan dan stimulus yang terlebih dahulu mengembangkan karakter menjadi seorang wirausaha sejati yang dimungkinkan dapat mendorong semangat bisnis untuk terus maju dan tidak mudah putus asa.

Hasil penelitian menunjukan bahwa variabel pendidikan kewirausahaan berpengaruh positif dan signifikan terhadap intensi berwirausaha, yang berarti perilaku yang menjadi proses akhir sistem pendidikan di FIA UB diharapkan memupuk pengembangan diri melalui bidang bisnis dapat meningkatkan intensi usaha setiap mahasiswa, oleh karena itu pengembangan setiap individu untuk meningkatkan potensi, percaya diri atau kerja kerasnya dapat meningkatkan motivasi usaha agar mencapai kesuksesan.

Hasil penelitian menunjukan bahwa variabel karakter wirausaha berpengaruh positif dan signifikan terhadap intensi berwirausaha, yang berarti program pendidikan yang dilakukan FIA UB mampu mengarahkan mahasiswa untuk lebih fokus atau berorientasi terhadap dunia usaha. Hasil penelitian menunjukan bahwa variabel motivasi usaha berpengaruh positif dan signifikan terhadap intensi berwirausaha, berarti bahwa mahasiswa harus mengembangkan terus kemampuan dan motivasi dalam kehidupan sehariharinya misalnya melalui metode pelatihan atau berkumpul dan diskusi dengan sesama pengusaha sehingga meningkatkan fokus atau minatnya selalu terhadap dunia bisnis yang menjadi tujuan karir selama ini.

Berdasarkan kesimpulan di atas, dapat dikemukakan beberapa saran yang diharapkan dapat bermanfaat bagi FIA UB maupun bagi pihak-pihak lain. Adapun saran yang diberikan, antara lain: Diharapkan FIA UB sebagai lembaga pendidikan tinggi yang fokus pada lingkup dunia bisnis dapat mempertahankan dan meningkatkan Pendidikan Kewirausahaan, karena variabel pendidikan kewirausahaan mempunyai pengaruh yang signifikan terhadap motivasi usaha maupun intensi berwirausaha.

Berdasarkan hasil penelitian ini, diharapkan pengembangan penelitian dengan topik pendidikan kewirausahaan mengenai masalah-masalah yang selama ini dihadapi dijadikan pedoman untuk penelitian selanjutnya. Mengingat variabel bebas dalam penelitian ini merupakan hal yang sangat penting dalam mempengaruhi intensi berwirausaha diharapkan hasil penelitian ini dapat dipakai sebagai acuan bagi peneliti selanjutnya untuk mengembangkan penelitian ini dengan mempertimbangkan variabel-variabel lain seperti modal sosial, inovasi, dan juga orientasi kewirausahaan yang merupakan variabel lain diluar variabel yang sudah masuk dalam penelitian ini. 


\section{DaftarPustaka}

Ali, Dehghanpour Farashah. 2013. The Proses of Impact of Entrepreneurship Education and Training on Entrepreneurship Perception and Intention: Study of Educational System of Iran. Journal Education+Training. EmeraldInsight.V olume. 55 Issue; 8/9. Pp 868-885.

Arikunto. 2007. Quantitatif Research Method. Jakarta: Salemba Empat.

Bygrave, S. 1998. Entrepreneurship in 10 D Theory.Research Gate.

Darpujianto. 2014. Pengaruh Pembelajaran Kewirausahaan terhadap Motivasi Berwirausaha pada Mahasiswa STIE dan STMIK ASIA MALANG.Jurnal JIBEKA. Volume 8. No 1.

Farhangmehr. Minoo, Goncalves. Paul and Sarmento. Maria. 2016. Predicting Entrepreneurial Motivation among University Students: The Role of Entrepreneurship Education. Journal Education+Training.Emeraldlnsight.V olume. 58 Issue; 7/8. Pp 861-881.

Ferreira, J.J. and Raposo, M.L. 2008, Entrepreneurial Intention: a care with psychological and behavioural approaches, Conference Proceedings, 31st Institute for Small Business and Entrepreneurship Conference on International Entrepreneurship, 5-7 November, 2008, Belfast.

Fregetto, E. 2002. Business Plan Or Business Simulation For Entrepreneurship Education? Developments in Business Simulation and Experiential Learning, Volume 29.
Hakim. Supriadi. 2003. Entrepreneurship Education. Jakarta; SalembaEmpat;.

[Hussain. Javed G, Scoot. Jonathan M, and Hannon. Paul D. 2008. The New Generation: Characteristic and Motivation of BME Graduate Entrepreneurs. Journal Education raining.Emeraldlnsight. Volume 50, Issue; 7 pp.582-596.

Hytti. Ulla, Stenholm. Pekka, Heinonen. Jarna, Seikkula. Jana. \&Leino. 2010. Perceived Learning Outcomes in Entrepreneurship Education. Education Training Journal. Emeraldlnsight. Volume. 52, Issue; 8/9. Pp587-606.

Lestari, Retno Budi danWijaya, Trisnadi. 2012.Pengaruh Pendidikan Kewirausahaan terhadap Minat Berwirausaha Mahasiswa di STIE MDP, STMIK MDP, dan STIE MUSI. Jurnal IImiah STIE MDP. Volume.1, No. 2.

Linan, Fransisco. J C Rodriguez.and Jose M Rueda. 2011. Factors affecting entrepreneurial intention levels: a role for education. Emeraldinsight.Volume 7:pp. 195-218.

Littunen, Hannu. 2010. Entrepreneurship and the Characteristics of the Entrepreneurial Personality. Education+Training Journal.Emeraldlnsight.Volume 6 Issue 6.pp 295-310.

Nazir, Mohammad. 2005. Research Method. Jakarta: Ghalia Indonesia.

Pathan, Saiman Karman. 2015. An Analysis of the Entrepreneurship Orientation Among Business Student : A case Study. Research Gate. 
Rakhmawati, A., Rahardjo, K., \& Kusumawati, A. Faktor Anteseden dan Konsekuensi Green Supply Chain Management. JSINBIS (Jurnal Sistem Informasi Bisnis), 9(1), 1-8.

Robert J. Taormina and Mei lao Kin. 2007. Measuring Chinese Entrepreneurial Motivation: Personality and Environmental Influences. Journal of Entrepreneurial and Behavior Research.Emeraldlnsight. Volume 13, Issue; 4 pp. 200-221.

Saiman, $\quad$ Leonardus. 2009. Entrepreneurship Theory. Jakarta. Salemba Empat..

Soutaris. V, Zerbinati. S and Al laham. A. 2007. Do entrepreneurship Programmes Raise Entrepreneurial Intention of Science and Engineering Students? The Effect of Learning, Inspiration and Resources.Journal of Business Venturing .Volume 22.Issue; 4.pp 565-591.

Sumarsono. 2010. Entrepreneurship II. Jakarta; SalembaEmpat; A.A. Anwar Prabu Mangkunegara. 2016. Manajemen Sumber Daya Manusia Perusahaan. Bandung: PT. Remaja Rosdakarya. 